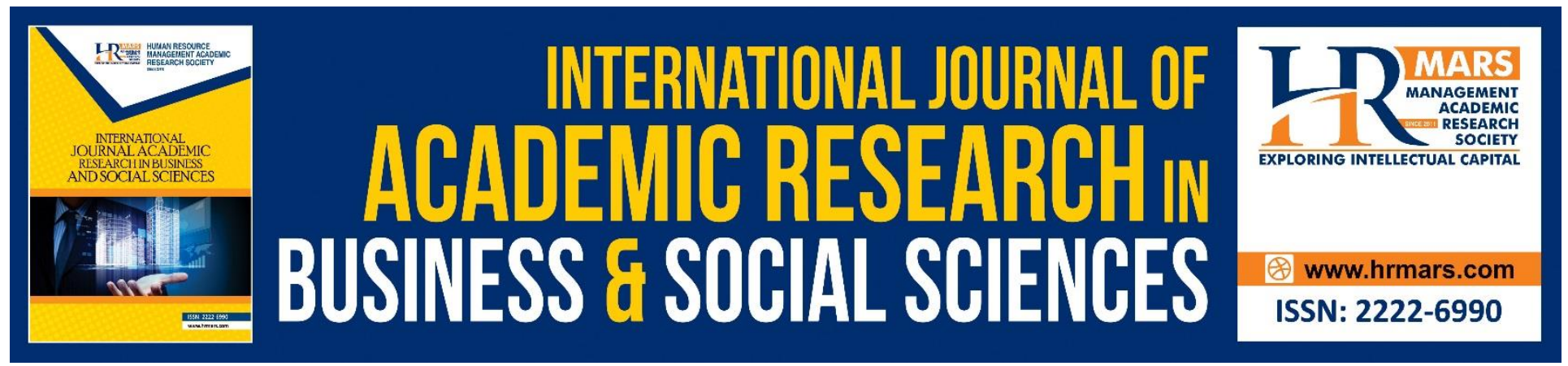

\title{
From the Past to the Present: A View of Teaching English as a Foreign Language (EFL) in Libya and the Role of Communicative Language Teaching (CLT) Approach
}

\section{Eman Abdussalam OWEN, Abu Bakar RAZALI, Iman Abdussalam ELHAJ}

To Link this Article: http://dx.doi.org/10.6007/IJARBSS/v9-i2/5580

DOI: $\quad 10.6007 /$ IJARBSS/v9-i2/5580

Received: 13 Jan 2019, Revised: 16 Feb 2019, Accepted: 21 Feb 2019

Published Online: 26 Feb 2019

In-Text Citation: (Owen, Razali, \& Elhaj, 2019)

To Cite this Article: Owen, E. A., Razali, A. B., \& Elhaj, I. A. (2019). From The Past To The Present: A View Of Teaching English As A Foreign Language (Efl) In Libya And The Role Of Communicative Language Teaching (Clt) Approach. International Journal Of Academic Research In Business And Social Sciences, 9(2), 459-476.

\section{Copyright: (c) 2019 The Author(s)}

Published by Human Resource Management Academic Research Society (www.hrmars.com)

This article is published under the Creative Commons Attribution (CC BY 4.0) license. Anyone may reproduce, distribute, translate and create derivative works of this article (for both commercial and non-commercial purposes), subject to full attribution to the original publication and authors. The full terms of this license may be seen at: http://creativecommons.org/licences/by/4.0/legalcode

$$
\text { Vol. 9, No. 2, 2019, Pg. } 459 \text { - } 476
$$

Full Terms \& Conditions of access and use can be found at http://hrmars.com/index.php/pages/detail/publication-ethics 


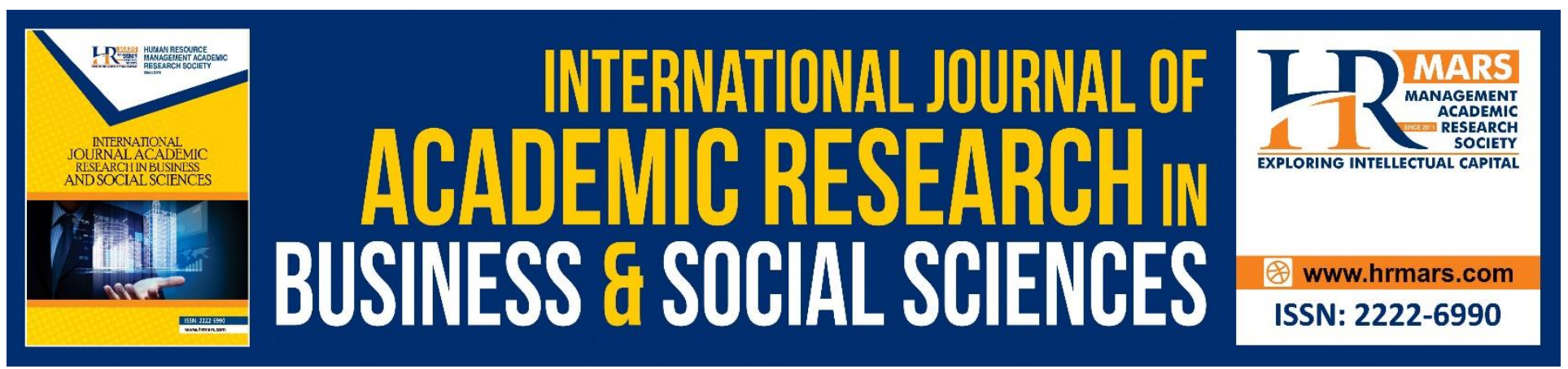

\title{
From the Past to the Present: A View of Teaching English as a Foreign Language (EFL) in Libya and the Role of Communicative Language Teaching (CLT) Approach
}

\author{
Eman Abdussalam OWEN \\ Faculty of English Language, Sabratha University, Libya \\ Email:emanaowen@yahoo.com
}

Abu Bakar RAZALI (PhD)

Faculty of Educational Studies, Universiti Putra Malaysia (UPM), Malaysia

Email:abmr_bakar@upm.edu.my*

Iman Abdussalam ELHAJ

Faculty of English language, Sabratha University, Libya

Email:Iman19822@gmail.com

\begin{abstract}
In this this paper, the authors will highlight the history of the Libyan educational system in general and the English as a foreign language education in particular. The authors look into the role of the different policies and decisions from the Libyan Ministry of Education that shaped its education system, particularly on the teaching and learning of English as a foreign language, as it exists today. The authors give a review that explains the impact of Gaddaffi's Regime on the Libyan education system and the problems, which arose at that time, and describe the history of the educational system since 1951 until the current education system used to date. Moreover, the authors discuss the history of English language teaching and the teaching methods used in the classroom with a background of how the communicative language teaching (CLT) approach was introduced in the Libyan classrooms. Finally, the authors will discuss the potentials and problems of CLT in the English language classroom.
\end{abstract}


INTERNATIONAL JOURNAL OF ACADEMIC RESEARCH IN BUSINESS AND SOCIAL SCIENCES

Vol. 9, No. 2, Feb, 2019, E-ISSN: 2222-6990 C 2019 HRMARS

Keywords: Communicative language teaching (CLT) approach, English language, English as Foreign Language EFL, Libyan education system.

\section{Introduction}

The education system is the backbone of any country. Education is an endless process and it is the first step towards change and development. The strength of the educational system in any country is based on the arrangements, which must be made to suit society's specific needs, and the labour market. As such, any government in the world tries their best to update the curriculum to the requirements of their own society and the worlds' standards. Undoubtedly, Libya, like any government in the world, also focused on improving its educational system. Historically speaking, the Libyan educational system has underwent a number of fundamental changes many times concerning the teaching curriculum at different levels of education in general, and English curriculum specifically (Elabbar, 2011). These processes of change, which was imposed by the Ministry of Education in Libya, was a reaction towards dealing with the problematic situations in teaching English because of the dissatisfaction with the old teaching methods and to enhance the quality of English Language teaching (Orafi, 2008). These changes were also required due to the increasing demand for competent English users in the Libyan educational community to master all the language skills.

The history of teaching English as a foreign language in the Libyan education system, and the language teaching practices including the methods adopted in the Libyan classroom are focused on to understand the role that CLT plays in the current Libyan context. Highlighting the potentials and problems that face students, teachers, administrators, etc. with the implementation of CLT in Libya can help overcome the difficulties they face and achieve the goals of this approach.

\section{THE EDUCATION SYSTEM IN LIBYA}

After the Libyan independence in 1951 from Italy under UN Trusteeship, greater attention was given to education by the new government (the United Kingdom of Libya) under king Idris leadership. This is when schools began to be built in big towns and cities, Koranic schools reactivated, and education became more accessible for people seeking knowledge (Deeb \& Deeb, 1982). Article 14 of the 1969 Libyan constitution declaration states "Education is a right and duty for all Libyans. It is compulsory until the end of preparatory schools or what is also called "basic education." After this declaration, education was not only accessible for essentially male students, as it was before the 1960's, but for both male and female students in Libya (Zarrough et al., 2001), in which education in Libya is made free for everyone for all stages starting from primary school to university level (Krayem, 2013).

Due to this change, and despite the culture, religious beliefs, and poverty, there was an increase in the number of students joining schools over time. For example, the percentages for female students in basic education (primary and preparatory) jumped from 11\% in the 1960's up to 48\% in the 1990's. Recently, the numbers of both genders is almost equal not only in preparatory levels of education but also in higher levels of education (Otman \& Karlberg, 2007, p. 127). For instance, the first university in Libya was established in Benghazi in 1955, where the number of enrolled students was about 13,418 for the academic year 1975/76. In 2004, the number rose to more than 200,000, and an extra 70,000 students were registered in the higher technical and vocational sector (Clark, 2004). 
INTERNATIONAL JOURNAL OF ACADEMIC RESEARCH IN BUSINESS AND SOCIAL SCIENCES

Vol. 9, No. 2, Feb, 2019, E-ISSN: $2222-6990$ ๑ 2019 HRMARS

According to figures as of 2010 (CIA, 2013) education in Libya continues to be high, with $95.6 \%$ of males and $82.7 \%$ of females over the age of fifteen are literate and study in the Libyan schools.

Libya is considered a highly conservative Islamic society and this had an impact on education (Deeb $\&$ Deeb, 1982). For a very long time the role of the student and teacher have been influenced by culture. The teacher is the source of knowledge and the sole authority in the classroom and therefore, should be always respected and never be interrupted and questioned. Whereas, students are expected to sit quietly, understand and memorize the information given by the teacher (Orafi, 2008). According to Ben Hamid (2010), teaching in Libya has always been based on the traditional methods and in many schools, it is still the same.

\section{The Gaddafi Regime and its Impact on the Libyan Education}

Since 1969, when the former Libyan president, Moammar Gaddafi came to power, significant changes were evident in the Libyan education system, such as the significant increase of primary schools in the country and primary education became compulsory. Then, in the 1970s, a new structure consisting of primary, preparatory, and vocational education was introduced (Orafi, 2008). However, the Gaddafi regime's policies and decisions as well as the education system were undertaken in an autocratic approach. Any decision or policy needed the president's approval and had to be according to his wishes or it would be changed (Elabbar, 2011). This resulted in an unstable education system in the country as it lacked the ability to produce graduates with the necessary life skills to meet the needs of the society. Most Libyan students were equipped with only knowledge with no practical training that were reflected in the long term. According to Gadour (2011), what the Libyan schools taught during this time was irrelevant to what students need in order to succeed in life, and this is why the Libyan education system was unable to produce graduates with necessary life skills, such as communicative skills and particularly foreign language skills.

The Gaddafi regime in Libya has affected the educational system in many ways especially in the way opposing political views and poor relationships between the country and the West have a great negative impact on the education process, particularly on the teaching and learning of the English language. As such, during Gaddafi's regime the English language has been taught on and off a number of times (Youssef \& Bose, 2015). This is because any political issue or misunderstandings between Libya and Western countries would result in compulsive decisions without considering the outcomes. For example, in April of 1986, there was an air raid by the United States of America and the United Kingdom against Libya. Due to this attack, a decision was made by the Libyan Ministry of Education under Gaddafi's reign (i.e., No. 195/1986), in which Colonel Gaddafi demanded to cut all relations with other countries and the English language to be deleted from the curriculum (The development of education in the Great jamahiriya, 2001). This policy was ordered by the colonel as a reaction to the actions of the West that obliged to stop any form of teaching the English language or French.

Moreover, the decision forced to discontinue any form of interaction with the west, whether it was political, educational, or economical. As a consequence of deciding to stop both the English and French languages in 1986, there was a gap of seven years where no use of English was found inside or outside the classrooms, or anywhere else in Libya at that time. This 'isolation period' is in line with 
Gaddafi's plan to 'eliminate foreign influence' (Clark, 2013). Mohsen (2014) claimed that when language teaching was resumed again in the year 1993, many problems rose. He explained that some of these problems are low proficiency levels in English and limited personnel to interact and communicate with other organizations and governments whether privately or publically, and therefore, this lead to isolation from the rest of the world. Khalid $(2017$, p. 12) indicates that this decision was described as the most painful period in the history of the Libyan educational sector, as it affected the education system for many years.

After the Libyan Revolution, whereby the Gaddafi's regime was overthrown, the new government tried to improve the level education in Libya and the Libyan education system experienced change towards focusing on language learning and teaching and putting human resource development as a priority.

\section{The Current Education System in Libya}

The current educational system structure in Libya, includes four main stages. In the first stage, which is the Kindergarten stage, where parents can register their four or five year old children in pre-school for one or two years. Then, in the second stage, which is called 'Basic Education' stage, the students officially start primary school at the age of six years. There is another option given by the Libyan Ministry of Education where parents engage their children in learning at an earlier age by home schooling them at the age of five (Zarrough,et al, 2001). The disadvantage of this option is that students must continue home schooling for at least three years before attending a public primary school. The basic education system is for nine years and it is divided into two parts, (a) six years for primary level and (b) three years for preparatory level. According to the decision No. (95) of the Libyan education policy, since 1975 , the basic education system stage was compulsory for all children until the age of 15 , and they are not allowed to work before this age.

After that, in the third stage, which is called the Secondary level, students undergo secondary level education for three to four years depending on their major that they choose at secondary school. Secondary level is divided into two sections, which are the academic section and the vocational and technical (or specialized secondary education). The first section, which is the academic section, is divided into two parts, scientific and social sciences. The second type is the vocational and technical section, which was formed in the 1980's, called the "New Educational Structure," focused on technical subjects (Clark, 2004). This section consists of two units. The first unit is called the vocational unit, which consists of seven fields: a) electrical, b) mechanical, c) carpentry, d) architectural, e) weaving, f) service, and g) productive vocation. Whereas, the second unit is the technical or specialized unit which includes six fields: a) basic science, b) geometrical and industrial science, c) medical sciences, d) agricultural sciences, e) social sciences, and f) fine arts and media (Zarrough, et al, 2001). The ages of students attending secondary school usually starts at the age of 13-15 for preparatory of middle level; and 16-18 years for high school students (Altaieb, 2013) After this stage, students can decide to continue their path in education and finish tertiary level or start looking for a job (Lagga \& et al. 2004). 


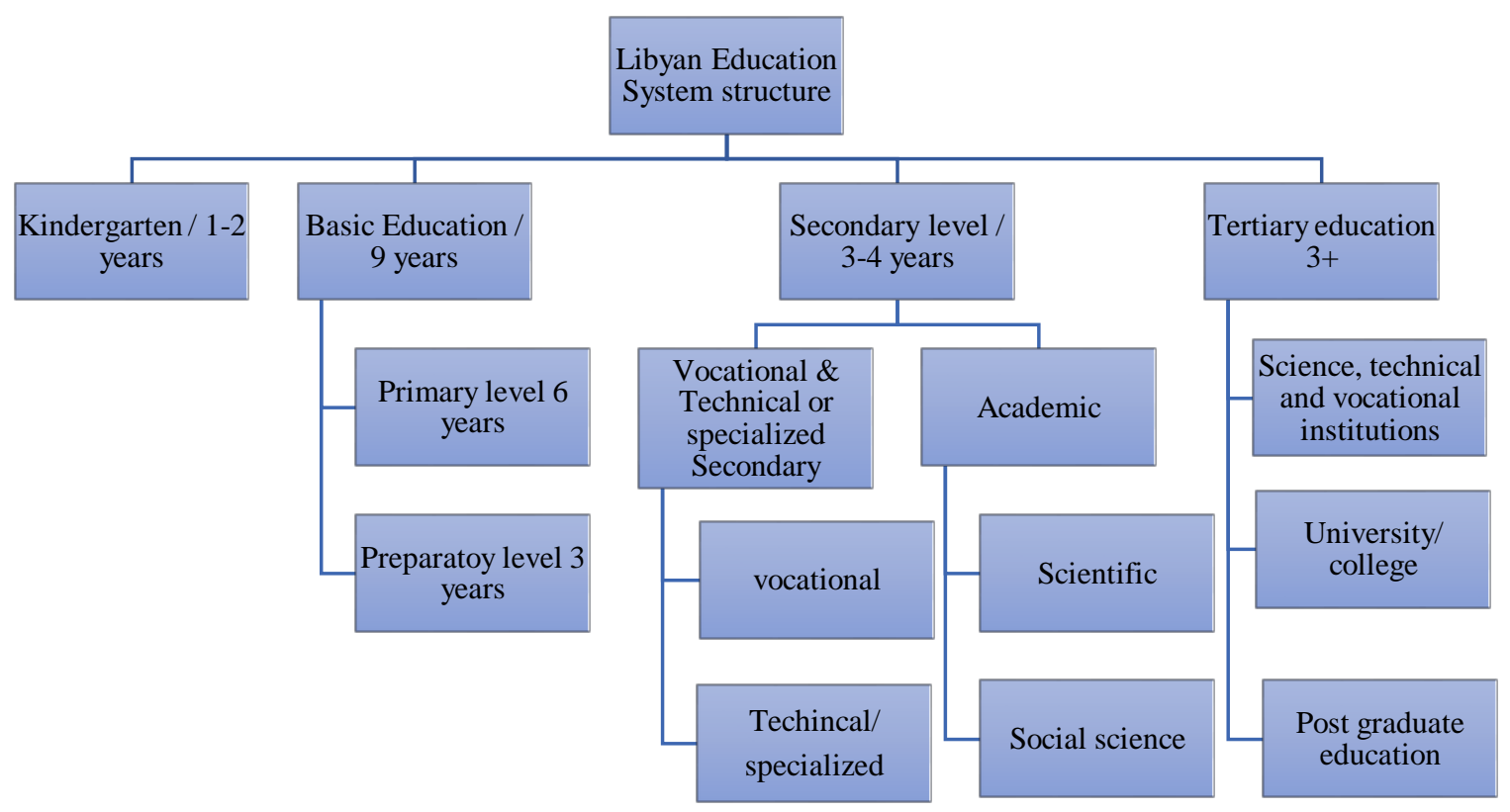

Figure1: The structure of Libyan education system.

Lastly, for the fourth stage or the Tertiary Education stage, students can choose to further their studies in either science, technical and vocational institutions or in colleges or universities. For the first option (i.e., science, technical and vocational institutions) the maximum duration of study is three years whereas, the second option (i.e., colleges and universities) is from four to seven years depending on the major of their studies. Some universities also offer postgraduate education (M.A. and PhD.) such as the Academy of higher studies, Tripoli University and Benghazi University (Clark, 2004).

Some of the general objectives of education in Libya according to General Peoples' Committees of Education is to "provide students with the opportunity to choose the specialization that suit their abilities and according to society needs". In addition to "aid students to acquire the skills of thinking and scientific analysis to comply with science development and to accomplish a balance between theoretical information and practical application" (GPCE, 2008, p. 4-5). More specifically, education in Libya is also to "help students master the Arabic and English language to communicate with the world, being able to develop students' sense of national identity and to be proud of the Arabic and the Islamic civilization" (GPCE, 2008, p. 5).

\section{ENGLISH AS FOREIGN LANGUAGE (EFL) TEXTBOOKS IN LIBYA}

According to Hashim (1997), the first English language textbook series in Libya was titled Basic Reading Book written by L.W. Lockhart. The textbook was given to preparatory level and it was taught by nationalities other than Libyans, such as Egyptians and Palestinians, for four lessons per-week for the whole academic year (Orafi, 2008). Later, the textbook series, entitled New Method (1930) by Michael West, who was an English language inspector in Libya, was introduced in the 1960's (ICA, 
1958). After that, the textbook was replaced by another textbook, which is called the Modern Reader (1950) by A. Johnson (Barton, 1968). This text-book was based on the Grammar translation method, which emphasized on learning vocabulary through reading. In 1965, a step to change the system of instruction of English language took place by the Libyan Ministry of Education, and a new textbook series was introduced, which was called English for Libya which was based on the direct method (Barton, 1968). However, the curriculum was criticized for focusing on memorization of isolated vocabulary, application of grammatical structures and on translating and understanding reading texts therefore, it was changed (Orafi \& Borg, 2009). While in the 1970's, a new textbook was presented called Living English for Libya, and it was introduced to two levels preparatory, and secondary students, and it focused on reading comprehension and grammar (Orafi, 2008).

Then, two new textbook series were introduced. The first by Mustafa Gusbi was entitled English for Libya, and the second was by Mustafa Gusbi and Roland John $(1974,1980)$, entitled Further English for Libya. Through the use of these textbooks Libyan English teachers were required to adopt the English culture as a vehicle for teaching the English language by using Western related topics as and the schools continued to use it until 1980's. This textbook series included three books: 1) Further English for Libya (1), 2) Further English for Libya (2), and Further English for Libya (3), in which each of these textbooks was accompanied by a workbook and a teacher's handbook. This textbook series continued until the Gaddafi regime to which the Ministry of Education in Libya's decision No. 195/1986 took place to stop teaching foreign languages (Mohsen, 2014). However, this step was quite controversial and was not approved by many educationist. For example, Otman and Karlberg (2007, p. 110) stated that "changing the school curricula in 1980's, favoring other subjects over the English language, and then omitting it was a fundamental and disastrous mistake." This is because the decision made by the Libyan Ministry of Education in the 1980's to stop teaching foreign languages affected the whole educational system and many issues kept rising. For example, students' low proficiency levels, a decrease of the number of professionals in the English language field, English language teachers forced to teach subjects other than their majors, and the isolation from the outside world (Mohsen, 2014).

In the academic year of 1993/1994, the teaching of English as a foreign language was resumed and continued to use the English for Libya textbook series, but during the first year the same book was used for all levels of education. This was due to the Libyan Ministry of Education's intention to catch up with the number of years the English language teaching stopped as the students were all at the same level of English language proficiency at that time. Then, another version of the textbook series, English for Libya, published by Garnet Education Company, was introduced in the academic year $2000 / 2001$ for primary and secondary levels. After that, in the academic year $2005 / 2006$, the third level primary were given another text-book, which was under the same name, and also published by Garnet Education publication, but was only used for one year. Then, in 2006/2007, this particular textbook series was presented only to $5^{\text {th }}$ and $6^{\text {th }}$ primary level students (Orafi, 2008). This deprived once again third year students from studying the English language again and therefore, it extended the English language-learning gap.

The new English language program in Libya aimed to develop the four major skills for language proficiency, but because the national syllabus was based on the traditional teaching methods, it did 
not achieve this goal (Mohamed, 1987). Mohsen (2014), stated that there was a need to change and improve the whole process of the Libyan English as a foreign language teaching following the CLT approach, which was believed to be able to achieve communicative competence. Thus, new textbook series were introduced which "emphasizes the need for changing the traditional role of teacher from a specialist and a sole source of knowledge into an assistant and a director to create the scene for the student and the active learner and even train students on the skills of thinking and analysis, installation, conclusion and practice" (Lagga et al., 2004, p. 28). In 2000, the new series of English for Libya which was written by Garnet publishing from the UK and representatives of the National Education and Research Centre of Libya (Orafi, 2008) was introduced. According to Macfarlane (2000), this text-book is designed to develop the grammatical system and increase vocabulary and master the four language skills. All Libyan public and private schools inside and outside of Libya (i.e., Libyan international schools) currently use it. It consists of two main books: 1) a student book and 2) a workbook. Teachers are given an additional book that will guide them through the units and activities, and it also offers answers to the questions in the textbook. The student book includes eight units, in which each one has a different theme. Within the unit, the four major skills are placed in separate sections or lessons. Moreover, grammar and vocabulary are also included in separate sections. Even though the skills are sectioned by lessons, they are intertwined and are meant to be taught together.

\section{TEACHING METHODS AND APPROACHES IN THE LIBYAN EFL CLASSROOM}

Historically speaking, English language education first began in Libya in the 1940's after the World War II. The first attempt to provide formal English instruction for primary level was in 1955, but it was quickly cancelled because there was shortage of teachers (Hashim, 1997). The English language had been taught to students from the age of 10 until the secondary level, but in 1973, it was moved back to students aged 13 (Khalid, 2017). In the 1980's English language was accessible for secondary students and higher but then soon afterwards the Ministry of Education abandoned it for all levels. In the late 1990's the English language was resumed and gradually presented to other levels of education, in which until the fifth grade of primary level was included (Elabbar, 2011). In the current English language system, which was implemented from the academic year 2000/2001 until now, the Libyan Ministry of Education requires students to usually take four English lessons per-week, and each one is forty to forty-five minutes long depending on the sequence of the lesson in the learning schedule. The first three lessons are generally forty-five minutes long and the lessons after breakfast session are forty minutes long (Macfarlane \& Harrison, 2008).

Throughout the years, many methods have been used in teaching English as a foreign language in Libya, starting from the traditional methods, such as Grammar-translation method (GTM), the Audiolingual method, the communicative approach and up to mixing the methods to reach the goal of learning. The Grammar Translation Method (GTM) focuses on grammatical rules and patterns and the goal of this method is to be able to read the literature of the target language. This is accomplished by learning the grammar rules of the language by the help of translating sentences and texts from the target language to the mother tongue and vice versa (Larsen-Freeman, 2000). The reading and writing skills are also focused on, but no attention is given to neither the speaking nor the listening skills. Accuracy and grammar forms in GTM are emphasized and the mother tongue is the medium of 
instruction (Richards \& Rogers, 2001). Ben Hamid (2010) pointed out that Grammar translation method (GTM) has been used by teachers in the Libyan English language classrooms starting from the first English textbooks and it is still used today. The class is teacher-centered and is based on translation into the mother tongue and the focus is teaching grammar rules whereas, communicative activities or materials are seldom used other than the whiteboard or blackboard. However, the focus on grammar rules has neglected vocabulary teaching and learning in the Libyan secondary school system, and thus reflects on the difficulties faced by students in communication skills (Ben Hamid, 2010). Along with Ben Hamid, other Libyan researchers (see Esmail \& et al, 2015; Kustati, 2011; Abduljalil, 2009; Orafi \& Borg, 2009,; Orafi, 2013) indicated that grammar based teaching or grammar based examinations are main problems in the education system, as they do not serve the goal of communicative competence.

There are also two other teaching methods that Libyan teachers use in their teaching of the English language. For one, they rely on the Audio-Lingual Method in which the learner's role is a reactive role by responding to stimuli, to which they have limited control over the content, and they are not encouraged to initiate interaction. The teacher's role in this approach is central in which he/she models the target language, monitors, corrects student mistakes, and directs the learning process (Larsen-Freeman, 2000). In this method, there is focus on accuracy through drilling, repeating and practicing the dialogue or sentence pattern and finally memorizing it. It pays attention to intonation and pronunciation (Richards \& Rogers, 2001). For example, listening and repeating drills were done in which the learner listens to the teacher and repeats what he/she says and responds to their commands. In addition, there is also the Direct Method (DM), which was widely understood among Libyan teachers but rarely used because it required complete use of the target language in the classroom (Suleiman, 2003). The Direct Method was an approach that required the use of the target language 100 percent in the classroom, but EFL teachers tended to sway from an approach to another while applying different techniques inappropriately, and this caused confusion. According to Elabbar (2011), the Direct Method was occasionally used in the Libyan context and by a small number of teachers and usually at university levels where the lecturer chose the curricula and method. Whereas, in school level in which the Libyan Ministry of Education as laid out the Libyan national curriculum and organized everything.

While there are benefits of using these approaches, some scholars argue that GTM, ALM as well as the DM do not encourage the use of different activities and materials that employed oral use of the language in the Libyan classroom to help the teaching process. Orafi and Borg (2009) criticized these methods by stating they are teacher-centered and taught each skill or aspect of language separately that did not meet Libyan students' needs. For instance, although GTM helps in mastering grammatical rules, it could not be of much help in communication or developing communicative competence among Libyan students. Teacher-centered approaches were not helping in reaching the aims of the education system for Libyan EFL students (Hmaid, 2014; Ben Hamid, 2011). Therefore, there was need for change in the English education scene in Libya, and the first step was taken by the Libyan government was introducing the new curriculum that was based on Communicative Language Teaching (CLT) approach. 
INTERNATIONAL JOURNAL OF ACADEMIC RESEARCH IN BUSINESS AND SOCIAL SCIENCES

Vol. 9, No. 2, Feb, 2019, E-ISSN: $2222-6990$ ๑ 2019 HRMARS

\section{POTENTIALS AND PROBLEMS WITH COMMUNICATIVE LANGUAGE TEACHING (CLT) APPROACH IN THE LIBYAN EFL EDUCATION}

In CLT, the attention has been shifted away from a teacher-centered approach to a student-centered approach, in which the focus is more on students to use and produce the language effectively, improve their basic communicative skills, and engage in effective communication in the target language. This is done through the combination of the four skills rather than learning about the target language itself. The main principle in CLT is that "Language is acquired through communication." (Howatt \& Widdowson 2004, p, 279). It was based on the idea a language is a communicative tool, its emphasis on learning to communicate through interaction between the teacher and students or between students themselves, this could be done by involving students in a variety of communicative activities and tasks which offer a great opportunity to practice their skills in various ways by taking different roles. In other words, students' experience would be in the actual use of language instead of learning the grammatical rules of the language. Savignon (1997) claimed that communicative competence states the ability of language learners to communicate meaningful language in social, contextual, and cultural contexts.

Due to the nature and appeal of the CLT approach, the communicative approach was introduced to the Libyan English language curriculum due to the demand for change and the necessity to increase communicative competence of Libyan graduates. The objective of the Libyan educational system was to have graduates that can interact, face new challenges, and be part of the developing world (Zarrough, et al, 2001; Lagga, et al, 2004). In 2000, Libyan teachers experienced the introduction of the new English curriculum in Libyan primary and secondary schools with the implementation of the CLT approach, which was different in terms of teaching pedagogy and curriculum materials from the previous one. The new Libyan curriculum suggested that English be used as much as possible in the classroom, as 'the aim for the students to communicate effectively and fluently with each other and to make talking in English a regular activity' (Macfarlane, 2000, p. 3). With the implementation of the CLT approach in Libya, the attention was given to develop Libyan students' competence and appropriateness, rather than mastering the grammatical rules as the traditional methods emphasized.

Many researchers have conducted studies on the use of CLT and its benefits at all levels of English as a foreign language (EFL) settings, such as China, Thailand, Japan, Korea, Taiwan, and Turkey, etc. (Li, 1998; Orafi \& Borg, 2009; Ozsevik, 2010; Akram \& Mehmood, 2011; Rahman 2015). One of the advantages of CLT is that it builds up a relationship between the teacher and the student (Chang \& Goswami, 2011; Rahman, 2015). In this regard, it enhances students' competence and confidence, encourages the use of pair work, and considered as a good opportunity for students to speak the target language, and strengthen their ability in the four language skills of listening, speaking, reading, and writing (Li, 1998; Macfarlane, 2000;). CLT also improves learners' confidence and gives a sense of fulfillment to the teacher and this method gives clarity to communication better than all the other methods of language teaching that focus on one skill more than the other (Akram \& Mehmood, 2011). 
Orafi (2008) and also Rahman and Karim, (2015) believe that EFL students are likely to participate actively in the classroom, and participate in a variation of tasks that help express their thoughts or opinions. Hence, the positive CLT outcomes can be achieved through implementing new CLT practices such as using Information computer technology (ICT) in communicative English programs rather effective learning for students (Bañados, 2013; Rahman, 2015). In addition, Richards (2006, p. 20) states that CLT increases pupils' interests, raises learners' awareness of a foreign language, provides information and exposure to the real target language. Littlewood (1981) stated that Communicative language teaching (CLT) is considered a valuable method or approaches that can be used by language teachers during their lessons as it provides learners with the opportunity to use the language to develop communicative needs.

However, many studies also reveal a number of complications that EFL teachers have encountered when implementing CLT (Li, 1998; Orafi \& Borg, 2009; Ozsevik, 2010; Akram \& Mehmood, 2011; Rahman 2015). In this respect, similar findings are in parallel with the situation in Libya. In the case of Libya, the introduction of CLT in Libyan English education was not without controversy. According to a report from (UNESCO, 1996) up to 1996 the communicative approach did not reach Libya - and hence the approach was very novel to Libyan teachers. In addition, the Libyan schools lack educational media, and there were no laboratories nor English language teaching specialists that CLT approach requires. According to Mohsen (2014), the educational system lacks necessary conditions such as limited time, classrooms, teaching aids, native speakers, and opportunity to practice the language. Moreover, because there is still a mismatch between the curriculum and the nature of examinations in Libya, it is difficult to fulfil the principles and fundamentals of Communicative Language Teaching CLT (Orafi \& Borg, 2009).

The vast shift in teaching the English language have also caused some difficulties to the Libyan students, teachers, and officials, because it was not presented slowly in the system rather it was imposed on them without prior arrangement nor proper training and materials (Elhaj, 2009). An obvious conundrum in using this new curriculum is the role played by its teachers. However, there are others who feel this particular EFL teaching approach is important and necessary to achieve Libyan education's goals. Though the new Libyan curriculum was connected with the world's standards, the teachers carry the ultimate responsibility for the success of the new curriculum. In this respect, teachers' reactions to deal with these demands differs. On the one hand, there are Libyan teachers who adopted the new curriculum and the CLT teaching approach easily, however; other teachers resisted the implementation of the approach due to their lack of knowledge, skills and experience (Orafi, 2014).

This transition from the more traditional teaching approach to the more student-centred approach is quite challenging to Libyan teachers because introduction of CLT to teachers was without prior notice nor arrangements. The curriculum required qualified teachers that had some kind of background about the new approach. Elhaj (2009) indicated that Libyan teachers were surprised and unprepared to cope with the new curriculum. Due to this issue, the proposed change was delayed or in some cases, did not take place at all in certain Libyan classroom settings. Moreover, there was no consideration towards teachers' beliefs or attitudes who are willing to make use of CLT in EFL 
INTERNATIONAL JOURNAL OF ACADEMIC RESEARCH IN BUSINESS AND SOCIAL SCIENCES

Vol. 9, No. 2, Feb, 2019, E-ISSN: $2222-6990$ ๑ 2019 HRMARS

contexts, and the contextual factors that might hinder the implementation process of the new curriculum and the CLT approach.

Alshibany (2014) claimed that Libyan teachers are fossilized in using the traditional methods of teaching, and their knowledge about CLT is very limited. She added that the main reasons behind the failure to implement CLT are teachers' lack of language proficiency and sociolinguistic competence and cultural factors. For example, although the new CLT approved textbooks recommend that students should work both in pairs and in groups, Libyan teachers preferred to avoid doing so. This is because Libyan teachers lack the ability to involve their students in practical activities inside the class.

According to Mohsen (2014), the Libyan educational system also lacks necessary conditions such as limited time, classrooms, teaching aids, native speakers, and opportunity to practice the language. Fullan (1991) indicates that teachers were not involved in the design of curriculum and the Ministry of Education asked them to implement it without a suitable background. After ELT inspectors received training by the publishers of the course book, language teachers were provided with only week of training before the beginning of the academic year. This was not enough because some teachers were uncertain of the effectiveness of the communicative approach and its activities in learning the target language and believe that learning can be through vocabulary and memorizing grammatical rules, which lead to learning a language (Al-Buseifi, 2003; Orafi, 2008).

Moreover, Libyan students too faced a new approach that is unfamiliar to them as this new approach was based on communication and focusing on all four skills, rather than the one they used, which requires memorizing grammatical structure, drilling and vocabulary learning. According to Orafi and Borg (2009), the implementation of CLT is quite challenging because Libyan EFL learners face problems in developing their communicative competence outside the classroom. This is generally because they do not have a supportive learning setting where they can practice and use English for communicative purposes. In addition, the condition of English language teaching and learning in the Libyan schools is unsatisfactory and most students encounter difficulties in participating in the oral activities and that it is why in many cases they do not bother to take part in the activities (Ahmad, 2001).

Overall, the transition from a traditional way of teaching to a communicative one is a step in the right direction but it needs a lot more than simply changing the curriculum or methodology, it requires competent teachers, materials, adequate class time, and small number or students per class. Orafi (2008) claimed that it is not always easy to ask teachers to implement a curriculum without looking at what this curriculum requires teachers to do. In order to strengthen teachers' practice of CLT, there must be intensive courses to be promoted all over the country to present the new curriculum preferably. Similarly, Orafi also proposed that there is a need for teaching training sessions and education programs in order to attain the planned objectives. According to Orafi (2014), it is first necessary to understand the principles of CLT, and then to investigate the extent to which teachers' current classroom practices reflect those suggested by the curriculum that promote CLT. In addition, it is important to study the beliefs that underpinned teachers' classroom practices in order to improve 
INTERNATIONAL JOURNAL OF ACADEMIC RESEARCH IN BUSINESS AND SOCIAL SCIENCES

Vol. 9, No. 2, Feb, 2019, E-ISSN: $2222-6990$ ๑ 2019 HRMARS

the English language teaching quality in Libya (Orafi, 2014). In addition, Rahman and Karim (2015) claim that forming encouraging conditions for EFL teachers to be optimistic about adopting CLT in the classrooms and facing the obstacles is crucial. Ozsevik (2010) states that" aligning CLT with traditional teaching practices seemed to be beneficial for EFL students".

\section{CONCLUSION}

Political issues and decisions before and after the Gaddafi regime have greatly influenced the Libyan educational system. Although there was a glimpse of hope with the new methodologies and curriculum in language teaching which were suggested in the late era of his leadership, the outcome was not as planned. The CLT approach has been around in the English educational system in Libya for a long period. Research indicates that even though the Libyan Ministry of Education appointed to implement this approach, it has not been practiced fully or implemented broadly. This is due to many reasons: 1) Libyan teachers doubting its effectiveness (Orafi, 2008); 2) the difficulties that teachers face while implementing it, e.g., large classes and low proficiency levels of teachers and students (Abduljalil (2009); and 3) the strict educational system from examination to allocated time for classes (Mohamed, 2014), among other issues.

The authors are in the same position as Abu-Khattala (2014), in which he indicated that CLT approach has yet a great influence on English language teaching in the Libyan context due to the challenges while implementing this approach, such as roles of the teacher and student, examination constraints and lack of language proficiency. As such, the authors believe that CLT implementation would be more effective if teachers are well equipped with sufficient knowledge and prepared in a way that enables them to deal with any obstacles arose in their classrooms. Teachers need to renew the materials used in their English classes, consider its implications, and look the teaching situation differently, which would create secure and enjoyable classes. In other words, if teachers are to implement the innovation successfully, they have to understand the theoretical underpinnings and what it reflects in classrooms application of the proposed change. After Libyan teachers are used to the ideas of CLT and are assured of its significance and effectiveness, it can be used with success. Fullan (1991, p. 199) stated, "people will always misinterpret and misunderstand some aspects of the purpose or practice of something that is new to them." In this respect, the authors believe that Libyan teachers' implementation of CLT is the result of their positive attitude and acceptance, while those teachers who prefer to cling to the traditional methods are trying to create a safe environment for themselves to avoid failure and any unpleasant results.

There is no perfect teaching method or approach, but it is crucial for the Libyan teachers to implement the appointed CLT method by the Libyan Ministry of Education, which are in accordance to the Libyan education system. At the same time, it is necessary to understand Libyan EFL students' and teachers' perceptions and attitudes towards the CLT approach and curriculum and take their opinion into consideration. It is crucial to investigate the effectiveness of the use of Communicative Language Teaching (CLT) approach, understand the Libyan teachers' apprehension in using this approach, and investigate students' difficulties in English speaking. Moreover, policymakers should always maintain the interest of the learner, teacher, and learning process to achieve the best results in the implementation of this nationwide teaching approach. Overall, this transition from a traditional 
way of teaching to a communicative one is a step towards the right direction. Thus, it needs a lot more than simply changing the curriculum or methodology; rather it requires careful planning, competent teachers, materials, adequate class time, and smaller classes. After all education plays a crucial role in the development of any nation.

This research is significant to all those interested in the field of EFL learning and teaching in the Arab world in general and the Libyan context in particular. It is crucial to highlight the problems that resulted from the government's policies and regulations that influenced the educational system considerably in order to tackle and overcome any impediments in language learning. Moreover, focusing on the methods and approaches used in language teaching and learning and their role in the Libyan context can provide an overview and contribute to the existing knowledge on implementing CLT in the language classroom. 
INTERNATIONAL JOURNAL OF ACADEMIC RESEARCH IN BUSINESS AND SOCIAL SCIENCES

Vol. 9, No. 2, Feb, 2019, E-ISSN: $2222-6990$ ๑ 2019 HRMARS

\section{REFERENCES}

Abduljalil, M. S. (2009). Teaching speaking in preparatory schools in Tripoli. . (Masters unpublished). Academy of higher studies, Ganzoor, Tripoli.

Abu Khattala, I. (2014). Introducing the communicative approach in Libya: Resistance and conflict. Faculty of Arts Journal, 4(8).

Ahmad, M. A. (2001). A critical evaluation of the error correction techniques used by Libyan teachers of English at the secondary schools. (Unpublished masters' thesis), The Academy of Graduate Studies, Tripoli, Libya.

Al-Buseifi, A. (2003). Difficulties in learning vocabulary with reference to Libyan secondary school students. (Unpublished MA Thesis), Academy of Graduate Studies, Tripoli-Libya.

Alharbi, H. A. (2015). Improving students' English speaking proficiency in Saudi public schools. International Journal of Instruction, 8(1), 105-116.

Al-Hosni, S. (2014). Speaking difficulties encountered by young EFL learners. International Journal on Studies in English Language and Literature (IJSELL), 2(6), 22-30.

Al-Nawrasy, O. (2013). The effect of native and non-native English language teachers on secondary students' achievement in speaking skills. Jordan Journal of Educational Sciences, 9(2), 243-254.

Altaieb, S. R. (2013). Teachers' Perception of the English language Curriculum in Libyan Public Schools: An investigation and assessment of implementation process of English curriculum in Libyan public high schools. (PhD). Denver, U.K

Abduljalil, M. S. (2009). Teaching speaking in preparatory schools in Tripoli. (Masters unpublished). Academy of higher studies, Ganzoor, Tripoli.

Akram, M. \& Mehmood, A. (2011). The need of communicative approach (in ELT) in teacher training program in Pakistan, in Language in India, 11, 5: 172-178.

Alshibany, E. (2014). Investigating Libyan Teachers' Perceptions of Communicative Language Teaching. Spain. IATED, November 2014, pp. 3978-3988.

Bañados, E. (2013). A blended-learning pedagogical model for teaching and learning EFL successfully through an online interactive multimedia environment. Calico Journal, 23(3), 533-550.

Barton, L.C (1968), Libya English Teaching 27 August 196530 June 1968, Serial No.899/BMS.RD/EDM, FR/TA/Libyed 24, UNESCO, accessed from http://unesdoc.unesco.org/images/0000/000087/008728eb.pdf on 11 July 2018.

Ben Hamid, N. S. (2010). Developing the Oral skills through vocabulary: A Case Study of Some Secondary School Students in Tripoli. (MA), Academy of Higher Studies, Ganzoor, Libya.

Carabajo Vallejo, A. (2011). Games as communicative activities to encourage oral production in children from ages 10 to 11. (BA), University of Cuenca Ecuador

Carless, D. R. (2001). Curriculum innovation in the primary EFL classroom: Case studies of three teachers implementing Hong Kong's target-oriented curriculum (TOC) (Doctoral dissertation). University of Warwick, UK.

Chang, M., \& Goswami, J. S. (2011). Factors Affecting the Implementation of Communicative Language Teaching in Taiwanese College English Classes. English Language Teaching, 4(2), 312.

CIA. The World Factbook. CIA. (2013). [Online]. Retrieved 24/5/18 from http://www.indexmundi.com/libya/demographics profile.html 
INTERNATIONAL JOURNAL OF ACADEMIC RESEARCH IN BUSINESS AND SOCIAL SCIENCES

Vol. 9, No. 2, Feb, 2019, E-ISSN: $2222-6990$ ๑ 2019 HRMARS

Clark, N. (2013). Education in a Transitional Libya. World Education News \& Resviews. https://wenr.wes.org/2013/07/education-in-a-transitional-libya

Clark, N. (2004) Education in Libya. World Education News \& Resviews.https://wenr.wes.org/2004/07/wenr-julyaugust-2004-education-in-libya

Deeb, M., \& Deeb, M. J. (1982). Libya since the revolution: aspects of social and political development. New York: Praeger Publishers..

Elabbar, A. A. (2011). An investigation of influences affecting Libyan English as Foreign Language University Teachers (LEFLUTS), teaching approaches in the language classrooms (PhD dissertation). University of Glasgow, UK.

Elhaj, E. A. (2009). Language teachers' attitude towards the new English course books. (MA). Academy of higher studies, Tripoli, Libya.

Esmail, A., Ahmed, A., \& Noreen, S. (2015). Why do Pakistani Students are Reluctant to Speak English. Academic Research International, 6(3).

Fullan, M. (1991). The Meaning of Educational Change. New York: Teachers College Press

Gadour, A. (2011). Power and Struggle for Education in Libya. In Educators of the Mediterranean.. Up Close and Personal (pp. 121-130). Sense Publishers.

GPCE (General Peoples' Committee of Education) (2008). The Development of Education: National report of Libya. Pepper presented to the International Conference on Education. Geneva, 2528 November 2008.

Hashim, S. (1997). Review of Teaching English in Libya-Textbooks Used in Preparatory and Secondary Levels. In ESP in the Arab World: Reality Check and Prospects Proceedings of the XVIIth MATE Annual Conference Erfoud.

Hmaid, Y. (2014). The impact of teaching oral communication strategies on English language learners in Libya , (Ph.D). De Montfort University, UK.

Howard, J. \& Millar, S. (2009). The applicability of principles for instructed second language learning: A South Korean perspective. The Asian EFL Journal Quarterly, 11(4), 31-57

Howatt, A. P. R., \& Widdowson, H. G. (2004). A history of ELT. UK: Oxford University Press.

Hymes, D (1972). On communicative competence. In: Pride JB, Holmes, J (eds.) Sociolinguistics: Selected Readings. (pp 269-293). Penguin, Harmondsworth.

Kennedy, C.,Doyle, P.,\& Goh, C. (1999). Exploring Change In English Languange Teaching. United Kingdom:Bath Press.

Khalid, K. A. A. (2017). Learning and Teaching in English: A Case Study of Higher Education in Libya (Doctoral dissertation). Liverpool John Moores University, UK.

Krashen, S. D. (1982). Principles and Practice in Second Language Acquisition. Learning, 46(2), 32769.

Krayem, A. (2013). Language Learning Strategies of English Specialization Secondary School Students in Libya (Doctoral dissertation). Universiti Pendidikan Sultan Idris, Malaysia.

Kustati, A. (2011). The Implementation of the Communicative Language Teaching Approach in Teaching Reading in Selected Rural High Schools in West Sumatra. (Ph.D.). UKM University, Malaysia.

Lagga, B., AbuGhenia, A., El-Hawat, A., Mahgoubi, G., Abusalum, A., \& Al-Abid, A., Ghiblawi, S. (2004). The development of education national report of Libya. The international conference on 
INTERNATIONAL JOURNAL OF ACADEMIC RESEARCH IN BUSINESS AND SOCIAL SCIENCES

Vol. 9, No. 2, Feb, 2019, E-ISSN: $2222-6990$ ๑ 2019 HRMARS

education. Quality education for all young people: Challenges, trends and priorities. Geneva: International Conference on Education.

Larsen-Freeman, D. (2000). Techniques and principles in language teaching. Oxford University.

$\mathrm{Li}, \mathrm{D}$. (1998). "It's always more difficult than you plan and imagine": Teachers' perceived difficulties in introducing the communicative approach in South Korea. Tesol Quarterly, 32(4), 677-703.

Lightbown, P., Spada, N. M.(2010). How languages are learned. USA: Oxford University Press.

Littlewood, W. (1981). Communicative language teaching: An introduction: Cambridge University Press.

Macfarlane, M. (2000). English for Libya: Teachers' book. Reading: Garnet Publishing Ltd.

Macfarlane, M., \& Harrison, R. (2008). English For Libya. UK: Garnet Pubilishing.

Mohamed, S. H. (1987). The Communicative Approach in Langauge Teaching and its Implications for Syllabus Design in Libya. (PhD), East Anglia, England.

Mohsen, A. H. S. (2014). Teaching English as a foreign language in Libya. Scientific Research Journal, 2, 85-64.

Omar, Y. Z. (2014). Perceptions of selected Libyan English as a foreign language teachers regarding teaching of English in Libya. (Doctoral dissertation). University of Missouri-Columbia.

Otman, W., Karlberg, E. (2007). The Libyan economy: economic diversification and international repositioning. NY: Springer Science \& Business Media.

Oradee, T. (2012). Developing speaking skills using three communicative activities (discussion, problem-solving, and role-playing). International Journal of Social Science and Humanity, 2(6), 533.

Orafi, S. M. S. (2008). Investigating Teacher's Practice and Beliefs in Relation to Curriculum Innovation in English Language Teaching in Libya. (PhD.). University of Leeds. UK.

Orafi, S. M. S. (2013). Effective Factors in the Implementation of ELT Curriculum Innovations. Scientific Research Journal, I, (V), 14-21

Orafi, S. M. S. (2014) Investigating Teachers' Classroom Practices: A Framework to Enhance the Quality of English Language Teaching in Libyan Secondary Schools. Journal of Human Sciences and Studies, El-Marj, Libya 284. ISSN: $2312-4962$

Orafi, S. M. S., \& Borg, S. (2009). Intentions and realities in implementing communicative curriculum reform. System, 37(2), 243-253.

Ozsevik, Z. (2010). The use of communicative language teaching (CLT): Turkish EFL teachers' perceived difficulties in implementing CLT in Turkey. (M.A). University of Illinois at Urbana-Champaign, USA.

Rahman, M. S. (2015). Implementing CLT at Higher Secondary Level in Bangladesh: A Review of Change Management. Journal of Education and Practice, 6(2), 93-102.

Rahman, M. S., \& Karim, S. M. S. (2015). Problems of CLT in Bangladesh: Ways to improve. International Journal of Education Learning and Development, 3(3), 75-87.

Richards, J. C. (2006). Communicative Language Teaching Today, New York: Cambridge. University Press.

Richards, J. C., \& Rodgers, T. S. (1986). Approaches and methods in language teaching. New York: Cambridge University Press. 
Richards, J., Rodgers, T. (2001). Approaches and methods in language teaching (second ed.). USA: Cambridge University Press.

Savignon, S. J. (1997). Communicative Competence Theory and Practice: Texts and contexts in second language learning, New York: McGraw Hill,

Shehiba, S. E., S. (2011). An investigation of Libyan EFL teachers' conceptions of the communicative learner-centred approach in relation to their implementation of an English language curriculum innovation in secondary schools. (PhD), Durham University, UK.

Suleiman, Y. (2003) The Arabic Language and National Identity. Washington, D.C.: Georgetown University Press.

UNESCO. (1996). Education Advisory Mission to Libya. Paris.

Zarrough, A. M., El-Hawat, A., Al-Abid, A., Al-Tagouri, A., Masoudi, A., Mahmmod, D., \& Ghiblawi, S. (2001). The Libyan national commission for education, culture and science. The development of education in the great Jamahiriya. . Geneva.

Youssef, A., \& Bose, H. (2015). Challenges In The Learning Of English As A Foreign Language In Libyan High School. IJEL, 5 (1), 17-22. 